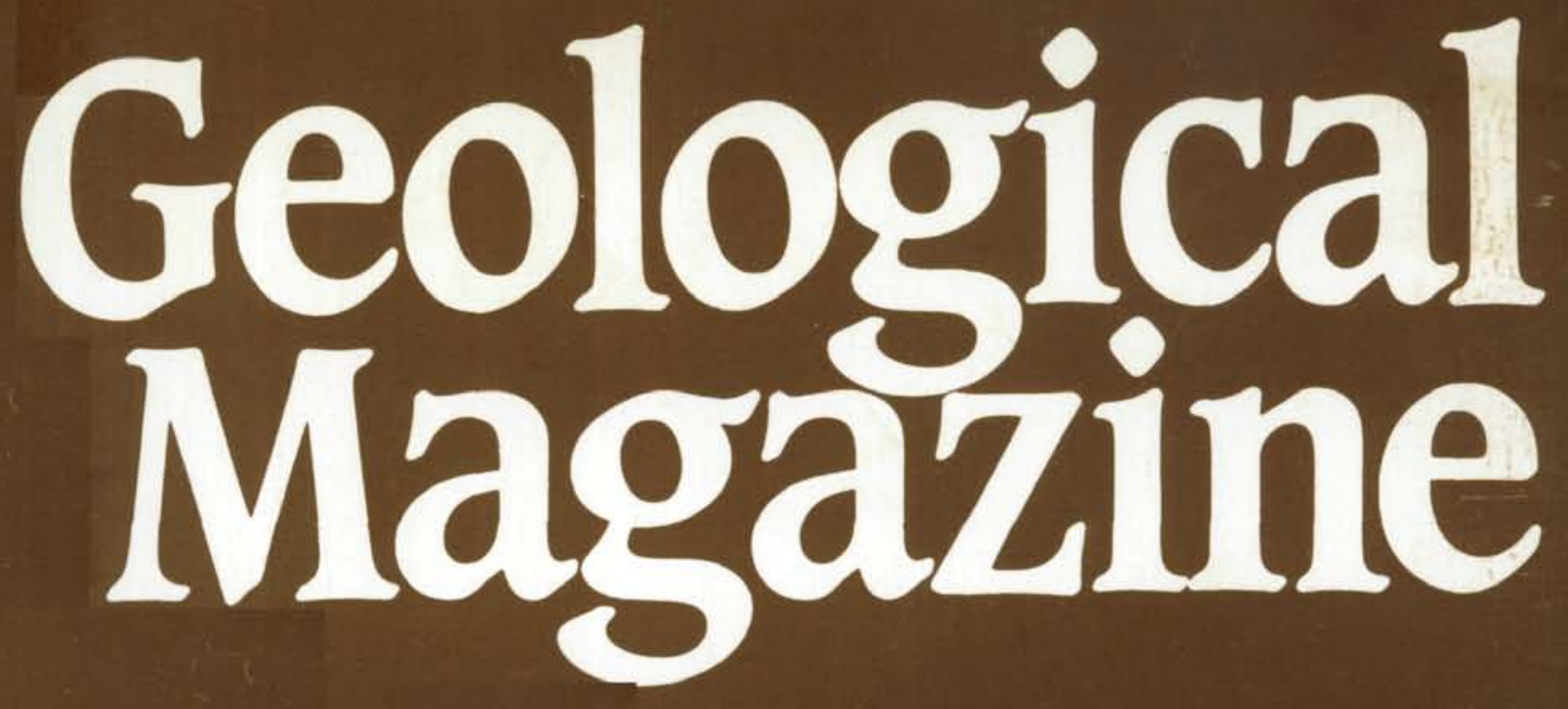

Volume 122, Number 1, January 1985 


\section{Geological Magazine}

\section{(founded in 1864, incorporating The Geologist, founded in 1858)}

Editors: W. B. Harland, C. P. Hughes, R. S. J. Sparks

Assistant Editor: MrS J. M. Holland

Associate Editors: SIR KINGSLEY DUNHAM, N. L. FALCON, Sir Peter Kent, F. W. Shotton, Sir James Stubblefield

Editorial Advisory Board:

Professor M. P. CowARD, Department of Geology, Imperial College, Prince Consort Road, London SW7 2BP, U.K.

Dr J. K. LegGetr, Department of Geology, Imperial College, Prince Consort Road, London, SW7 2BP, U.K.

Professor B. D. WeBBY, Department of Geology and Geophysics, University of Sydney, N.S.W. 2006, Australia.

Dr B. W. D. YARdLeY, Department of Earth Sciences, University of Leeds, Leeds LS2 9JT, U.K.

The Geological Magazine was originally established in 1864 and has been published continuously ever since.

It covers the whole field of earth sciences and welcomes papers which, provided they are of scientific merit, are also controversial in nature. It is the policy of the editors to encourage short papers so that all readers can expect to find at least one major item of interest in each part.

A section is devoted to scientific correspondence. Book reviews are of two kinds: essay reviews either review a group of books on related subjects or enable an author to discuss a particular topic in relation to the account given in a recently published book; in addition there are shorter reviews of recent books. The list of publications received provides a useful check list which is used by many librarians.

The editors wish it to be known that authors alone are responsible for the correctness of their references.

(c) Cambridge University Press 1985

Copying

This journal is registered with the Copyright Clearance Center, 21 Congress St., Salem, Mass. 01970. Organizations in the USA who are also registered with C.C.C. may therefore copy material (beyond the limits permitted by sections 107 and 108 of US copyright law) subject to payment to C.C.C. of the per-copy fee of $\$ 05.00$. This consent does not extend to multiple copy for promotional or commercial purposes. Code 0016-7568/85/2828-0001 \$05.00.

For all other use, permission should be sought from the Cambridge or New York offices of the Cambridge University Press.

Geological Magazine (ISSN 0016-7568) is published every two months in January, March, May, July, September and November. Six parts form a volume.

Orders, which must be accompanied by payment, should be sent to any bookseller or subscription agent, or direct to Cambridge University Press, The Edinburgh Building, Shaftesbury Road, Cambridge CB2 2RU. Subscriptions in the USA or Canada should be sent to Cambridge University Press, 32 East 57th Street, New York, NY 10022. The subscription price of volume 122, 1985, is $£ 63$ net (US $\$ 160.00$ in the USA and Canada) including postage; separate parts cost $£ 12$ net (US $\$ 30.00$ in the USA and Canada) plus postage. Second class postage paid at New York, NY, and at additional mailing offices. POSTMASTER: send address changes in USA and Canada to Geological Magazine, Cambridge University Press, 32 East 57th Street, New York, NY 10022.

Claims for missing issues can only be considered if made immediately after receipt of the subsequent issue.

Back Volumes: Vols. 1-60 out of print. Vols. 61-102: Enquiries to Wm Dawson \& Sons Ltd, Cannon House, Folkestone, Kent. Volume 103 onwards are available from Cambridge University Press.

Advertising: Details of advertising in Geological Magazine may be obtained from the publisher. 